\title{
THE ROLE OF SALT WATER AND THE POLITICAL-ECONOMIC CONDITIONS ON THE EVOLUTION OF SOVATA RESORT (ROMANIA)
}

\section{F. KOVÁCS ${ }^{1}$}

\begin{abstract}
The history of salt exploitation has overlapped the history of human civilization since prehistoric times. Salt has had an important role over the time, both in trade and in maintaining good health. In the areas where it came into contact with natural water springs, therapy-based baths emerged and have treated ailments since early times. By adapting to the trend set in mid- $19^{\text {th }}$ century Europe, areas with balneary potential in Transylvania, including Sovata, started to be turned to good account and the foundation for balneary resorts, which later were to become quite famous, was laid. The true valorization of these spas was accomplished only at the turn of the $20^{\text {th }}$ century, when the first modern treatment establishments and the accommodation buildings were constructed. This period is considered to be the golden age of Transylvania's resorts.

Sovata was first mentioned as a healing place in a 1597 letter, which contains an invitation for a sick man to regain health. In 1948 the spas, including Sovata Balneoclimaterica S.A., were nationalized, thus making them more accessible to the public. Nowadays, Sovata is a modern resort according to the European standards, bearing the same touristic and curative potential known for centuries. Nevertheless, the glamour and charm of the old times was wasted.
\end{abstract}

Keywords: salt resources, salt lakes, salt springs, spa, Sovata

\section{INTRODUCTION. THE IMPORTANCE OF SALT IN A HISTORICAL CONTEXT}

The ways salt is utilized are diverse, as it is one of the main useful rocks in the Earth's crust and a component of organic substances and living organisms. Salt is a mineral without which life is unconceivable, being the one that provides "an osmotic balance necessary in the operation of any living organism." ${ }^{2}$

In addition, since ancient times, salt has been used to preserve food. This property and the fact that this mineral is unalterable, made it be considered of divine origin, an element of purity, health and immortality. As a consequence, it was used in many rituals and mentioned in myths. The worth of salt was sometimes so great that it was exchanged at par for gold.

Transylvania has constantly been very attractive to all the populations in the region, and many wars were fought for the control of salt mines and roads. ${ }^{3}$

\footnotetext{
${ }^{1}$ University of Architecture and Urbanism „Ion Mincu” Bucharest, Romania, e-mail: ferenc_kovacs@ymail.com

${ }^{2}$ Camelia Bianca Toma, Geomorfositurile pe sare din Depresiunea Transilvaniei şi valorificarea lor turistică, rezumatul tezei de doctorat, Cluj-Napoca, 2012, p. 13.

${ }^{3}$ The Transylvanian salt roads are considered those roads that were used for the transportation of salt. In the Transylvanian Basin, these roads are laid in a radius leading to all directions.They are of two
} 
Within this context, salt can be considered as an important factor in people`s settlement, with major and continuous influence over the development of localities.

The presence of salt in outcrops and the existence of numerous salt springs in Sovata, ensured a multimillenia habitation for the communities.

\section{THE SALT EXPLOITATION IN SOVATA AND THE EARLY DAYS OF BALNEOTHERAPY}

The first references on salt mining in Sovata date back to the Roman period, when a road was built from Apulum (Alba Iulia) to the mining area. Nowadays, there is no longer any center of salt exploitation in the Sovata area. ${ }^{4}$

Currently there are 8 lakes in Sovata, grouped in the north-east side of the city. The biggest lake is Bear Lake with the length of $456 \mathrm{~m}$, perimeter of $1223 \mathrm{~m}$, surface of $41.270 \mathrm{~m} 2$ and a medium depth of $6 \mathrm{~m}^{5}{ }^{5}$ This lake was formed after a landslide in $1875 .{ }^{6}$

Lake Aluniș is formed in the place of an old medieval salt mine, has a surface of $3.670 \mathrm{~m} 2$ and a maximum depth of 7,4 m. The Green and Red lakes are formed in sinkholes after the dissolving of the surface of the salt massif. ${ }^{7}$

The above mentioned lakes have a high concentration of salt in their composition. Lake Mierlei (487 m2), Lake Paraschiva (1200 m2) and Lake Tivoli have very low concentrations of salt, being considered fresh water lakes. ${ }^{8}$

The spa culture is one of the oldest cultural assets, and its forms of manifestation in different historical periods and geographical areas, are diverse. Thus, the culture of baths existence and use is often characteristic to a particular civilization. The spa culture is an organic part, not only of the health and medical science, but also of the religion and daily habits, and in some cases it is linked to artistic events, too. In the Hungarian Empire there used to be a particular spa-related type of life, which today represents a unique phenomenon in the history of culture. ${ }^{9}$

Tourism is a particular form of enhancing the natural resources and anthropic heritage of a certain territory.

Sovata was first mentioned as a place for healing in a letter written in 1597, in which, lord Michael Kornis extends an invitation to István Báthory of Poland, who was ill, to come to Sovata in order to recover. ${ }^{10}$

types; on land and on water (on the Mures, Somes, Olt rivers). The Salt Road has been used since pre-Dacian period (later developed by the Romans) until the late nineteenth century, when the railway network was developed.

${ }^{4}$ Ibidem, p. 14.

${ }^{5}$ Camelia Bianca Toma, Geomorfositurile pe sare din Depresiunea Transilvaniei şi valorificarea lor turistică, p. 112.

${ }^{6}$ Kiss Lajos, Földrajzi nevek etimológiai szótára. II, Budapest, 1988, p. 318.

${ }^{7}$ Camelia Bianca Toma, Geomorfositurile pe sare din Depresiunea Transilvaniei şi valorificarea lor turistică, p. 112

${ }^{8}$ Ibidem, p. 113.

${ }^{9} \mathrm{http} / / /$ www.korunk.org/?q=ro/node/10949 - accessed 08.12.2016

${ }^{10}$ Urseanu F., Sovata mic îndreptar turistic, Editura Meridiane, București, 1965, p. 10. 
Another written record of Sovata resort with healing salty waters can be found in 1715, in István Halmágyi’s memoirs. ${ }^{11}$

In the following centuries, spas are almost forgotten until the late eighteenth century, when some of them began to be touristically attended again.

Spa treatment was done empirically through clinical observation by doctors and lay people, who obtain favorable results which persist over time. Thus, balneotherapy start to be developed in the mid-nineteenth century. The existing types of treatment are bath and sludge treatment completed by the beneficial influence of the climate and mineral waters. ${ }^{12}$

The first guest house in Sovata was built in 1844 by Baroness Simén Györgyné and János Tolnai who wanted to host tourists in the village. The concept of the constructions belongs to Dósa Dániel and Sándor Bereczki who no longer accept improvised holes and take important measures regarding the construction of a resort equipped with pools, restaurants and appropriate accommodation facilities. ${ }^{13}$

In 1850 Sovata became a healthcare resort ${ }^{14}$, and people would bathe "around a pool in which the salty waters flowed from the surrounding springs." ${ }^{15}$

\section{THE GOLDEN AGE OF SOVATA RESORT}

In 1873 Băile Géra (Lower Resort) was founded at the initiative of a local wealthy man, Veress József, who built on the dried valley of a salty stream a pool for cold baths and six cabins for hot baths. In the following years, more baths were arranged, reaching a number of 12 . This is the time when the first villas are built near the above-mentioned baths. In 1876, the licence for the lake water to be used for bathing is obtained and Sovata becomes a certified resort in 1884 . $^{16}$

József Veress`s resort's glory days spanned the 70s and the 80s of the nineteenth century. Hundreds of tourists visited the new resort to benefit from the healing properties of the salty water. Apart from the local wealthy people, tourists would come from distant areas. In 1881 the resort started to be visited by tourists from Budapest ${ }^{17}$ and in 1882 the resort is visited by 214 people. ${ }^{18}$

Illyés Lajos built a house around the Ursu Lake in 1893, used as a summer residence. The Upper Resort obtained the licence in $1901 .{ }^{19}$

\footnotetext{
${ }^{11}$ Halmágyi István, Naplói 1752-1753, Halmágyi János és id. Halmágyi István élete és végrendelete, Athenaeum r.-társulat könyvnyomdája nyomása, Budapest, p. 409-410.

${ }^{12}$ Eugen Morariu, Staţiunile balneo-climatice din Republica Populară Română, Editura Consiliului Central al Sindicatelor, Bucureşti, 1955, p. 30.

${ }^{13}$ Kővári László, Erdélyország statisztikája, I, Kolozsvár, 1847, pag. 56-57

${ }^{14}$ Camelia Bianca Toma, Geomorfositurile pe sare din Depresiunea Transilvaniei şi valorificarea lor turistică, Teză de doctorat, Cluj-Napoca, 2012, p. 189.

${ }^{15}$ Urseanu F., Sovata mic îndreptar turistic, p. 10.

${ }^{16}$ Eugen Țereanu, Sovata mic îndreptar turistic, Editura Sport-Turism, București, 1989, p. 22-23.

${ }^{17}$ Fekete Árpád, Józsa András, Szőke András, Zepeczaner Jenő, Szováta 1587-1989, Múzeumi Füzetek 15, Haáz Rezső Kulturális Egyesület, Székelyudvarhely, 1998, p.10.

${ }^{18}$ Eugen Țereanu, Sovata mic îndreptar turistic, p. 23.

${ }^{19}$ Ibidem, p. 23-25.
} 
By means of its baths, Sovata became the only city in the Land of salt. At the beginning, "Băile Géra" were considered small country baths. But the healing waters, especially those of the Black Lake, turned Sovata into a well-known resort. Once the Bear Lake had appeared, Sovata, especially the Upper Resort, built by the latest standards by Sófalvi Illyés Lajos, became one of the most popular baths.

The development of Sovata was positively influenced by the construction of the Blaj-Praid railway. In 1898, the Sărățeni station was built, yet, the railway to Praid was completed in 1906. The railway reached Sovata in 1905, thus providing a connection between tourists living in remote areas and the resort. ${ }^{20}$

The development of the baths was facilitated by the construction of the access roads to the resort in 1904. Inside the resort new roads were built that facilitated the access to different buildings. The same year, the owner built a confectioner`s shop and a lounge for socialization. In 1906 the Main Street (Rose Street) was laid and, soon afterwards, another six villas were built. ${ }^{21}$

In the early years, villas "appear like mushrooms after a rain". ${ }^{22}$

This is obvious if one takes a close look at figures 2 and 3 (compare the first urban plan from 1881 in fig. 1 to the plan of the resort in 1909 in fig.2) which show the amplitude of the resort development during the golden age. In the right side of fig. 2 there is a list that contains the name of all the villas. The popularity of the resort can be seen in the number of visitors within this period fig. 1 . The maximum number of visitors in this period was recorded in 1911 when the resort was visited by 4056 people, out of who, 1766 were permanent and 2290 were temporary tourists.

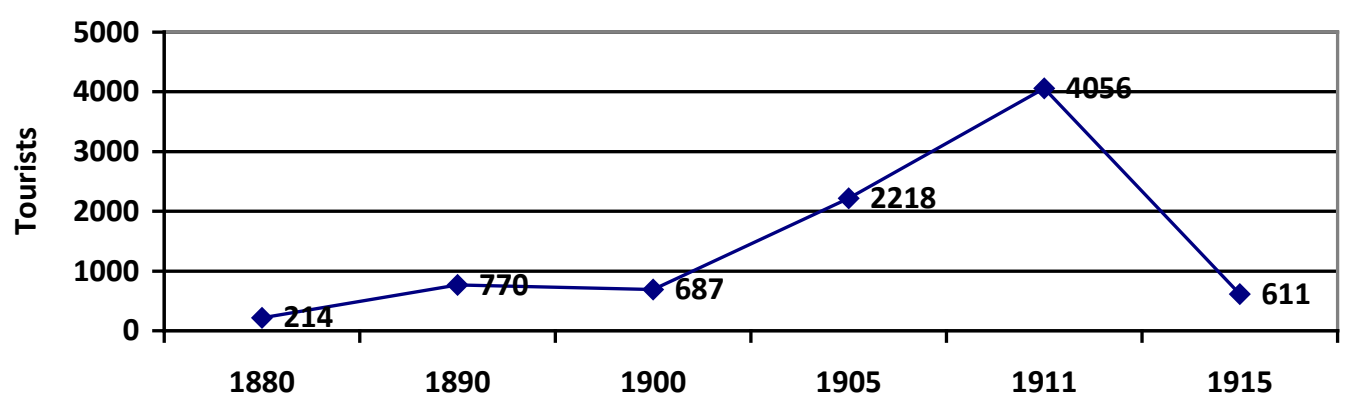

Fig. 1. Number of tourists during the golden age

This way, Sovata became one of the leading baths in our country, a fact that is also proved by the number of guests. In 1913, trains would arrive from Budapest via Arad every day. ${ }^{23}$

\footnotetext{
${ }^{20}$ Egyed Ákos: Falu, város, civilizáció - Fejezetek Erdély gazdaság- és társadalomtörténetéböl 18481914, Editura Kriterion, București, 1981, p. 158-160.

${ }^{21}$ Józsa András, Szováta első fürdője, Hazanéző, Korond, 2005, p. 244.

${ }^{22}$ Fekete Árpád, Józsa András, Szőke András, Zepeczaner Jenő, Szováta 1587-1989, p.244.

${ }^{23}$ Ibidem, p.257.
} 


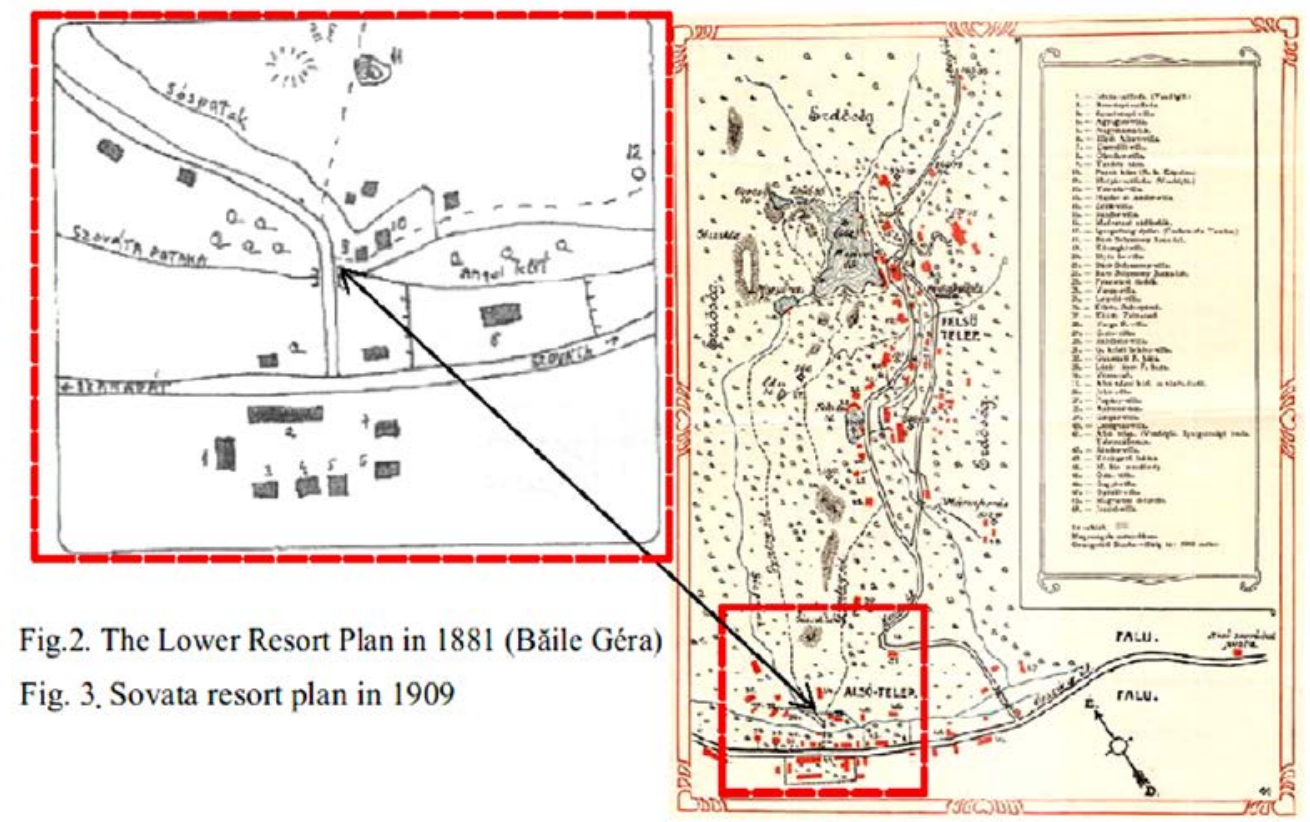

\section{THE RESORT IN THE INTERWAR PERIOD}

The development of the resort was stopped by World War I. Once the front got closer, people from both the village and the resort started to be evacuated. Soldiers destroyed many facilities and buildings. In addition, Count Beldi's villa was also burnt down, and the same faith was shared by both the restaurant and the café. ${ }^{24}$

World War I destroyed the resort not only economically, but it caused even more important damage to villas and buildings. On the margin of Ursu Lake, Illyés's treatment facility burned together with the hotel. After 1918, some of the owners moved to Hungary abandoning their properties. Consequently, between 1918 and 1920 the effervescent life of the resort ceased almost completely. ${ }^{25}$

However, the lakes, therapeutic factors, the beauty of the landscape revived the baths. A growing interest in the land and villas in Sovata can be noticed. By applying the land law 41 properties were confiscated from Jew and Hungarian owners and given to Romanian citizens. ${ }^{26}$

After it had gone bankrupt, the company founded by Illyés Lajos (who died in 1926), was bought in 1925 by the National Peasant's Party which, under the control of the Bank for Agriculture, founded a joint stock company. The medical manager of the company was dr. Marius Sturza. ${ }^{27}$

\footnotetext{
${ }^{24}$ Fekete Árpád, Józsa András, Szőke András, Zepeczaner Jenő, Szováta 1587-1989. p.257.

${ }^{25}$ Ibidem, p.258.

${ }^{26}$ Ibidem

${ }^{27}$ Fekete Árpád, Józsa András, Szőke András, Zepeczaner Jenő, Szováta 1587-1989, p.258.
} 
During this period Sovata used to have two hotels, (one with 32 rooms and another with 18 rooms), 74 villas with a total of 417 rooms and 510 beds for rent, two restaurants, a confectioner`s shop and a reading room. Ursu Lake included 130 bath cabins and 22 cabins for hot baths. In the resort there was also a ballroom, a tennis court and facilities for canoeing on the Ursu Lake. In 1924 a solarium was built for sunbathing by the Lake. A beauty treatment parlour was added in 1925 being extended with a terrace overlooking the lake. ${ }^{28}$

In the 30s, after the economic crisis investments were re-launched and several villas and hotels were built. ${ }^{29}$ In 1932, in the resort there were four hotels, 110 villas with 1,600 rooms and 2,600 beds. ${ }^{30}$

Regarding the number of visitors, the statistics made in 1942 shows that the resort had 4943 permanent and 860 temporary tourists (a total of 5803). ${ }^{31}$

\section{THE COMMUNIST ADMINISTRATION PERIOD}

In 1948 Balneoclimaterica Sovata S.A. was nationalized including 140 villas with 2,000 rooms and 3,000 beds. In the following years, new modern buildings are built, old villas are renovated and new methods of treatment are introduced. $^{32}$

In 1955 the resort is equipped with three establishments for bathing. The most important is the Ursu Lake establishment, where tourists could take salt baths in 30 bathtubs. It also contained rooms for hydrotherapy. In the same year, the Géra establishment had 12 bathtubs and 100 cabins on the lake shore. ${ }^{33}$ On the shore of the Black Lake, the 3rd establishment, there was a mud bath with 5 cabins with bathtubs, restrooms and beds for mud wraps for both men and women.

In 1967 the three modern pavilions were equipped for electrotherapy, hydrotherapy, inhalations, aerosols and mud wraps. There also were beautifully arranged parks and the resort included a gym, sports grounds, swimming pool, beach, baths and an open-air theatre. ${ }^{34}$

In 1978 the accommodation capacity was as follows: Hotel Sovata with its own treatment base $\left(1^{\text {st }}\right.$ class- for 300 persons $)$, Aluniş Hotel $\left(1^{\text {st }}\right.$ class - for 250 persons), Făget Hotel ( $1^{\text {st }}$ class - for 250 persons) Căprioara Hotel ( $1^{\text {st }}$ class - for 40 persons), several villas and private homes. Black Bear Inn, the property of the consumer cooperative had 80 beds and cottages with 120 beds. ${ }^{35}$

\footnotetext{
${ }^{28}$ Eugen Țereanu, Sovata mic îndreptar turistic, p. 25.

${ }^{29}$ Fekete Árpád, Józsa András, Szőke András, Zepeczaner Jenő, Szováta 1587-1989, p.261.

${ }^{30}$ Eugen Țereanu, Sovata mic îndreptar turistic, p. 26

${ }^{31}$ Fekete Árpád, Józsa András, Szőke András, Zepeczaner Jenő, Szováta 1587-1989, p. 266.

${ }^{32}$ Urseanu F., Sovata mic îndreptar turistic, p. 11.

${ }^{33}$ Eugen Morariu, Staţiunile balneo-climatice din Republica Populară Română, p. 236.

${ }^{34}$ Costin Ştefănescu, Staţiuni balneare şi climatice din România, Editura Meridiane, București, p. 127.

${ }^{35}$ Laviniu Munteanu, Ghidul staţiunilor balneoclimatice din România, Editura Sport-Turism, Bucureşti, 1978, p. 218.
} 


\section{THE RESORT TODAY}

In 2010 there still were 1200 beds in 9 hotels, 1000 beds in 50 villas, 300 beds in three camps for school children and preschoolers, 150 beds in 25 rural pensions, 100 beds in inns and motels, 100 beds in camp grounds and cabins and countless places in private houses. ${ }^{36}$

The "Sovata Salt Road" project was completed at the end of 2015. The value of the project was 5,06 million lei and was co-financed by the European Regional Development Fund (Regional Operational Programme 2007-2013). ${ }^{37}$

The main objective of the project is the development and the modernization of tourism infrastructure in Sovata in order to turn to enhance the natural resources and to improve the quality of touristic services. ${ }^{38}$

In this project the following investments are taken into consideration: The Eco-didactic Ursu Route and Salt Road, The Western and Tivoli Tourist Alley, Facilities around Ursu Lake and The Alley around Red Lake and Green Lake. ${ }^{39}$

\section{CONCLUSIONS}

Despite considering salt nowadays as a trivial, easily accessible element, with no significant value, this never used to be the same in the past.

Until the invention of refrigeration methods in the nineteenth century, salt was and still is a way of preserving food.

In addition, until the emergence of modern medicine, people had sought treatment for various illnesses. That might explain the great development of balneotherapy in the nineteenth century and in the early twentieth century.

In Sovata, the exploitation of salt resources along the time, led, besides the numerous economic advantages to a less intended utilization, namely, the appearance of salt lakes, which proved to be ideal in the treatment of many diseases.

The most flourishing period of the resort takes place at the turn of the 20th century, afterwards this being mostly maintained and brought to standards.

The constructive and plastic experience reached within such balneary programs is a benefit for the whole architecture and has, therefore, a highly important role in the history of architecture. ${ }^{40}$

Oswald Spengler asserted that "the evolved man is an animal who builds cities". The universal history is the history of the urban man. Peoples, states, policies and religions, all arts and sciences rely on the only form of archaic human existence:

\footnotetext{
${ }^{36}$ Camelia Bianca Toma, Geomorfositurile pe sare din Depresiunea Transilvaniei şi valorificarea lor turistică, Teză de doctorat, p. 192.

${ }^{37}$ http://www.transilvaniabusiness.ro/Drumul-Sarii-noua-atractie-turistica-a-Sovatei/ - accessed 08.12 .2016

${ }^{38}$ Ibidem

${ }^{39}$ Ibidem

${ }^{40}$ Gheorghe Curinschi Vorona, Istoria arhitecturii în România, Editura Tehnică, București, 1981, p. 9.
} 
the city" ${ }^{41}$. Each city has its own history of development, and, in the same time, its affiliation to certain conceptual categories is obvious.

It is necessary to mention that the disappearance of any element in the original image of any spa complex, leads to the disappearance of a remarkable witness to the late nineteenth century and early twentieth century spas, taking into account the fact that "modern times put a pressure on old towns, often abolishing changing or altering them, but always keeping old elements worthy of attention." ${ }^{42}$

In this context, in my opinion, the resort's cultural and architectural value has decreased considerably since its days of glory. Even if today one can notice that Sovata is a modern resort with the same curative and touristic potential, known for centuries, the charm it used to have 100 years ago is mostly lost. This is due mainly to the gradual dereliction of the villas, hotels and parks which once embellished the idyllic image of the old time resort.

\section{REFERENCES}

1. Camelia Bianca Toma, Geomorfositurile pe sare din Depresiunea Transilvaniei şi valorificarea lor turistică, Teză de doctorat, Cluj-Napoca, 2012.

2. Costin Ştefănescu, Staţiuni balneare şi climatice din România, Editura Meridiane, București, 1967.

3. Egyed Ákos, Falu, város, civilizáció - Fejezetek Erdély gazdaság- és társadalomtörténetéböl 1848-1914, Editura Kriterion, București, 1981.

4. Eugen Țereanu, Sovata mic îndreptar turistic, Editura Sport-Turism, București, 1989

5. Fekete Árpád, Józsa András, Szőke András, Zepeczaner Jenő, Szováta 1587-1989, Múzeumi Füzetek 15, Haáz Rezső Kulturális Egyesület, Székelyudvarhely, 1998

6. Gheorghe C. Vorona, Istoria arhitecturii în România, Editura Tehnică, Bucureşti, 1981

7. Halmágyi István, Naplói 1752-1753, Halmágyi János és id. Halmágyi István élete és végrendelete, Athenaeum r.-társulat könyvnyomdája nyomása, Budapest.

8. Józsa András, Szováta első fürdője, Hazanéző, Korond, 2005.

9. Kiss Lajos, Földrajzi nevek etimológiai szótára. II, Budapest, 1988.

10. Kővári László, Erdélyország statisztikája, I, Kolozsvár, 1847.

11. Laviniu Munteanu, Ghidul staţiunilor balneoclimatice din România, Editura SportTurism, București, 1978.

12. Mihaela Ioana Maria Agachi, Clujul modern - aspecte urbanistice, Editura UT Press, Cluj-Napoca, 2009.

13. Spengler Oswald, Det Untergang des Abendlandes, vol. II, München, 1923.

14. Urseanu F., Sovata mic îndreptar turistic, Editura Meridiane, București, 1965.

15. http://www.agerpres.ro/social/2015/12/16/orasul-sovata-a-finalizat-proiectuldrumul-sarii-de-unde-se-pot-admira-doua-locuri-unice-in-lume-18-11-55

16. http://www.transilvaniabusiness.ro/Drumul-Sarii-noua-atractie-turistica-a-Sovatei/

17. http://www.korunk.org/?q=ro/node/10949

\footnotetext{
${ }^{41}$ Spengler Oswald, Det Untergang des Abendlandes, vol. II, München, 1923, p. 105.

${ }^{42}$ Mihaela Ioana Maria Agachi, Clujul modern - aspecte urbanistice, Editura UT Press, Cluj-Napoca, 2009, p. 1.
} 